Marquette University

e-Publications@Marquette

Theology Faculty Research and Publications

Theology, Department of

$1-1-2014$

\title{
The Experience of a Pastoral Advocate and Implications for the Church
}

Bryan Massingale

Marquette University, bryan.massingale@marquette.edu

Published version. "The Experience of a Pastoral Advocate and Implications for the Church," in More than a Monologue: Sexual Diversity and the Catholic Church: Voices of Our Times. Eds. Christine Firer Hinze and J. Patrick Hornbeck II. New York: Fordham University Press, 2014: 91-95. DOI. (c) 2014 Fordham University Press. Used with permission. 


\section{Fordham Scholarship Online}

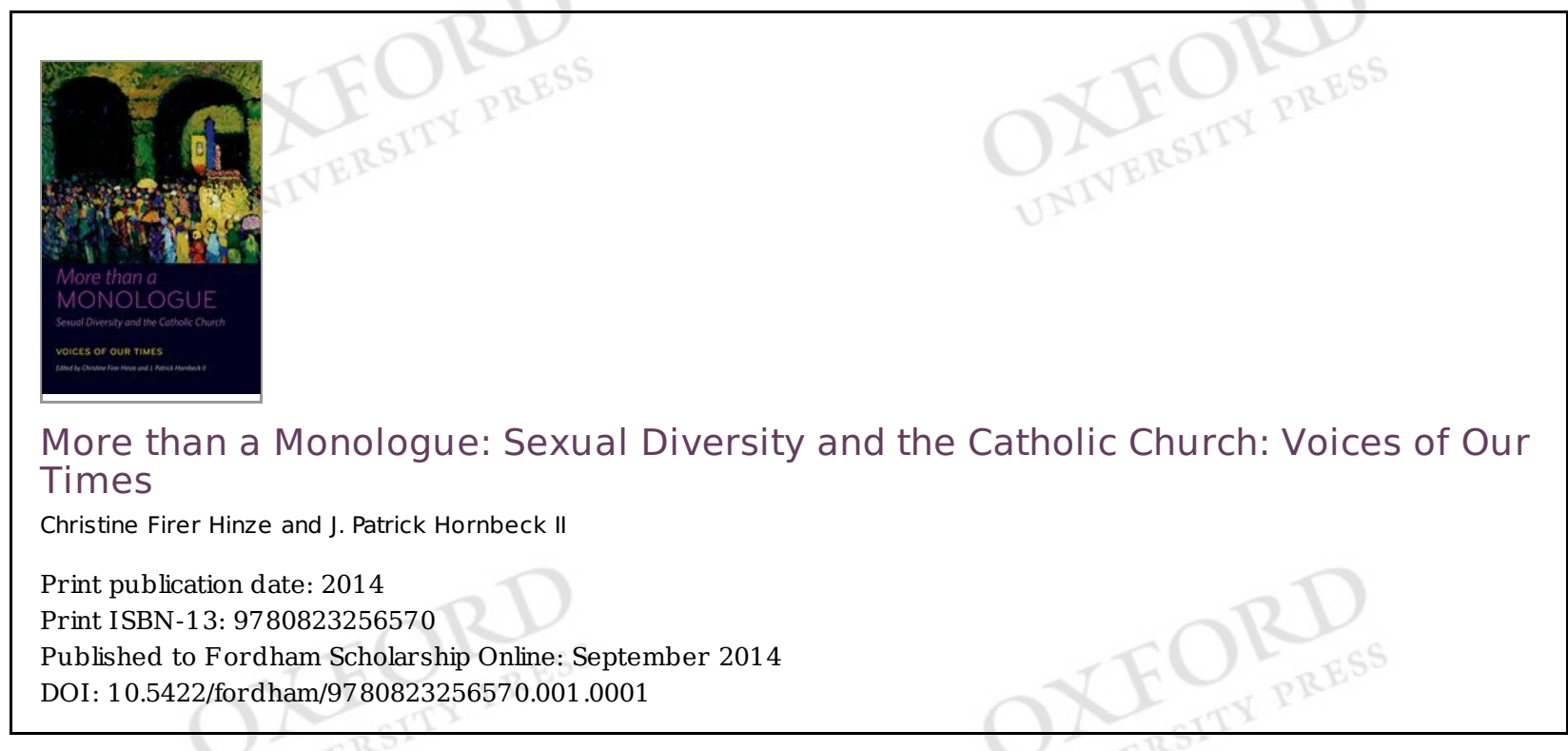

The Experience of a Pastoral Advocate and Implications for the Church

Bryan N. Massingale

DOI: $10.5422 /$ fordham/9780823256570.003.0009

\section{[-] Abstract and Keywords}

This chapter presents a critique-based on the chapter's author's own experiences as a university teacher, parish minister, and pastoral advocate-of the deleterious effects of what he calls "the pervasive climate of fear" and reactivity that surrounds even modest attempts at open conversation among Catholics about sexual diversity and the church. It suggest that this climate of fear is debilitating and dangerous, especially within a faith community charged by Jesus to "be not afraid." Left unaddressed, this fear has wide-ranging effects that threaten the well-being not only of LGBT Catholics but of all Catholics and indeed the very mission and identity of the church.

Keywords: fear, Catholic Church, sexual diversity, faith, LGBT Catholics

This reflection on Catholicism and LGBT realities flows from my multiple and overlapping identities as a priest and pastor, professor and scholar, and man of color. In it, I wish to consider the experience that attends being an advocate for justice for LGBT persons within the Catholic Church and what attentive listening to that experience may reveal about this faith community.

One of the defining experiences that shapes my perspective on LGBT issues occurred when I co-facilitated a session several years ago for students at Marquette University on "Culture and Sexual Identity." Over the course of the evening, we examined how various cultural groups construe human sexuality in general and homosexuality in particular. About thirty students attended; twenty identified themselves as gay/lesbian and also stated that they had some form of Catholic religious formation. None of these twenty, however, currently identified as belonging to the Catholic Church. I asked them why. Their reasons varied, but one young man expressed a common sentiment. He said, "It's hard enough to figure out who I am and how to live my sexuality without having to take on the Catholic Church as well." He shared this view with neither rancor nor sadness but simply as a self-evident fact.

I was no stranger to difficult conversations with LGBT persons about Catholic faith and ethics, yet for some reason these young adults' matter-of-fact dismissal of the church deeply affected me. Indeed, it broke my heart. I thought, "Surely our faith must have something more affirming and life giving to offer them." My heartbreak fueled a resolve to develop and offer a course on "Homosexuality and Christian Ethics," which explores the full range of complex positions that Christians have on LGBT issues.

Today, I continue to maintain a deep and abiding conviction that—at its core-Catholic faith can and should be more affirming 
of the diversity (p.92) of gender identity and expression. In all honesty, however, my experiences in trying to create spaces for a more positive and life-affirming message have sorely tried and tested this conviction.

Let me describe two of these experiences. First, in the fall of 2006, I published a reflection in my local diocesan newspaper on a proposed amendment to my state's constitution that would not only further prohibit same-sex marriages-which were already illegal-but also foreclose any legal recognition of same-sex committed relationships. I argued against that measure on the grounds that it went beyond mere support for "traditional marriage" and in fact endangered the human rights of many individuals and families. Without endorsing same-sex marriage, I used very traditional Catholic moral reasoning, as well as arguments employed in similar circumstances by then-Archbishop Levada of San Francisco and then-Bishop Niederauer of Salt Lake City, to argue that a "no" vote on this amendment was the best way to safeguard all of the Catholic values at stake. The stance I took on this question, however, was contrary to the guidance being given by Wisconsin's bishops.

To say that the article was noticed would be an understatement. ${ }^{1}$ Internet bloggers fervently denounced me as a "renegade priest" who "misleads the faithful" and "encourages immoral conduct." One even opined that I was "spreading Satan's fumes" throughout the archdiocese. Other writers offered commentaries that are too vile and hateful for public sharing. Even five years later, when we meet at various gatherings, some church leaders make it a point to tell me that they believe that my ethical analysis of this legislation was flawed. It is safe to say that writing this now dated and very modest article has cast a pall over my relationships with many Catholic bishops.

These experiences have been replicated with increasing intensity in the years that have followed. To offer a second example: In March 2011, I was part of a briefing for members of Congress and their staffs that discussed a Catholic justice perspective on LGBT-related legislation pending before Congress. As my students would say, "major drama" ensued over my presence at this event. Church officials attempted to curtail or curb my participation on the grounds that it was sponsored by groups who dissented from authentic church teaching on same-sex acts. My local bishop made an unprecedented request that I submit the text of my remarks to him prior to delivering them. And the Internet firestorm that erupted in (p.93) the briefing's wake made the 2006 experience seem like a dress rehearsal. Fanned by conservative Catholic websites, I was assailed with letters that accused me of having "a spirit of sexual perversion," denounced me for holding "duplicitous views" that are "absolutely inexcusable for a Catholic priest," and encouraged me to "do the honorable thing" by leaving the Catholic Church and joining the Episcopalians-a refuge for "clergy of your ilk." Some letters were so worrisome that I was advised to inform law enforcement, and I did turn them over to my university's Public Safety office.

These two events are representative of the range of experiences that I and many others, particularly priests, typically endure when we attempt to affirm LGBT persons in the church: intimidation, appeals to loyalty, a summons to obedience, and, when these fail, being denounced as "bad priests," "traitors," "suspect," "disloyal," and-perhaps the most ecclesiastical of opprobria-“imprudent."

I do not relate these experiences in an appeal for special sympathy. Other advocates and allies have had experiences similar to or worse than mine. I share these because I want to go underneath them and examine what they signify and reveal about the Catholic faith community's relationship to and understanding of its LGBT members. I contend that such experiences signal a pervasive climate of fear, one that borders on hysteria. ${ }^{2}$

Discussing the diversity of sexual identities and gender expressions among us arouses deep and, sadly, well-founded fears for many supportive pastoral ministers, scholars, and even some bishops: fears of investigation, intimidation, letter-writing campaigns, and silencing; fears of loss of preferment, livelihood, church membership, and/or a cherished vocation; fears of hassle and harassment; fears over the denial of tenure and/or promotion; and most pointedly, fear for one's very safetyeven from fellow believers. Catholicism's relationship with LGBT persons is such that even modest attempts at discussing issues such as gay bullying and gay teen suicide—on which there should be little controversy—regularly generate such wariness and anxiety that enormous sums of energy must be spent to "keep peace" in the community and to assure potential critics of one's loyalty to the church. Just as regularly, this climate of fear leads, at best, to silence, avoidance, and coded speak (that is, where an audience has to read between the lines to hear what the speaker is really intending to say). At worst, this climate entails duplicity, complicity, and doublespeak (that is, where the speaker or author says one thing in public and (p.94) another in private). Fear is costly. The cost of silence, duplicity, and complicity is betrayal: the betrayal of one's convictions, one's values, one's beliefs, one's very self.

But-and I want to emphasize this point-this climate of fear is costly not only for LGBT persons and their allies. This fear has deep implications for Catholicism itself. Such pervasive fear signals a faith community that is deeply anxious about its identity. One can only conclude that dialogue on LGBT issues arouses such anxiety and hostility because, in real ways, it threatens-or at least is experienced as threatening to-an ecclesial self-understanding so fundamental that such discussions must be stopped, controlled, and silenced even at great cost. This self-understanding functionally declares that "Catholic" = "straight." 3 That is, at the heart of the story that Catholicism has told about humanity, and integral to the way that the Catholic faith community officially identifies itself, is the belief that heterosexual persons, heterosexual love, heterosexual intimacy, and heterosexual friendship-and only these-can unambiguously and without qualification mirror holiness and mediate the Divine. ${ }^{4}$ This operative self-understanding of Catholicism functions despite rhetorical appeals to universality. Its 
overriding influence helps explains Catholic allies' many adverse experiences with faith-based LGBT advocacy, no matter how modest these attempts may be. Moreover, the power of this self-understanding is such that it exists regardless of and serves to undermine the church's official and perhaps even sincere affirmations of personal respect and pastoral concern for LGBT persons. ${ }^{5}$

Why, then, is this climate of fear so significant for the nature of Catholicism? Why does it call for serious reflection and concerted response, not only for the sake of LGBT persons and their allies but for the sake of our very identity as church? Because such profound fear and deep anxiety, I contend, are profoundly contrary to the Gospel and compromise the integrity of the church itself.

This challenge to the church's integrity as a vehicle of and for God can be expressed in the following troubling yet fundamental questions: Why, and how, have issues of gender and sexual expression become so defining of Catholic identity that contrary voices must be so proactively policed and silenced and dialogue of any sort is so deeply to be feared? Further, what are the deep theological, moral, and practical implications that follow from the conviction that the infinite love of God can never be found in loving same-sex relationships? (p.95) For example, wouldn't this conviction be a kind of idolatry, given the Christian faith commitment that "God is love" and abides in all loving persons (1 John 4:16)? What, then, are the existential and pastoral challenges of belonging to a faith community that publicly espouses such an idolatrous, or at least severely deficient, belief?

I know that such questions are too complicated for this specific contribution, which focuses not on theological matters but rather lived experiences. They are, however, among the pressing questions that my experiences as a pastor, scholar, educator, and member of the Catholic community bring to the surface. I believe that conversation on such probing questions is at the heart of what must happen if the church is to proclaim effectively the life-giving message that all are truly radically equal in dignity in the sight of God-a conviction that I still hold, despite its being sorely tried and tested. ${ }^{6}$

Notes:

(1). The line of argument I used and the ensuing controversy were covered in depth by the local newspaper. Bill Glauber, "Discussion or Dissent? Priest Offers an Alternate Take on Marriage Vote," Milwaukee Journal Sentinel (October 27, 2006), http://www.jsonline.com/news/milwaukee/29216494.html.

(2) . Indeed, Richard McCormick, arguably the most influential U.S. Catholic moral theologian of the twentieth century, noted over a quarter-century ago that "The modern need in the Catholic community is a pacific, unthreatened, open understanding and restructuring of sexual ethics. Whether this will or can occur is doubtful. Even modest attempts ... are met with such panic, fear, and denunciation that scholars can only be discouraged from the attempt." Richard McCormick, Health and Medicine in the Catholic Tradition (New York: Crossroad, 1984), 104; emphasis added.

(3) . This is a riff off of a formulation I developed in a recent work that contends that in U.S. (and global) Catholicism, "Catholic" = "white." For this discussion, see Bryan N. Massingale, Racial Justice and the Catholic Church (Maryknoll, N.Y.: Orbis, 2010), 79-82.

(4) . For example, this is the deepest implication of the current prohibition against ordaining men with "deep-seated same-sex attractions." See Congregation for Catholic Education, "Instruction for the Criteria for the Discernment of Vocations with Regard to Persons with Homosexual Tendencies in View of Their Admission to the Seminary and to Holy Orders" (2005), no. 1 ,

http://www.vatican.va/roman_curia/congregations/ccatheduc/documents/rc_con_ccatheduc_doc_20051104_istruzione_en.html.

(5). For example, even a document that condemns all same-sex genital expression as manifesting self-indulgence at the same time counsels that gay and lesbian persons are to be treated with dignity and respect. See Congregation for the Doctrine of the Faith, "Letter to the Bishops of the Catholic Church on the Pastoral Care of Homosexual Persons" (1986), nos. 7, 10, http://www.vatican.va/roman_curia/congregations/cfaith/documents/rc_con_cfaith_doc_19861001_homosexualpersons_en.html.

(6) . This conviction, despite current ecclesial practices to the contrary, is attested to in the magisterium's own documents. See The Compendium of the Social Doctrine of the Church, heading for no. 144: "The Equal Dignity of All People"; the Compendium then declares "the radical equality ... of all people." What this volume intends, I believe, is to promote and stimulate dialogue on the practical and doctrinal implications of this belief in the "radical equality of all people."
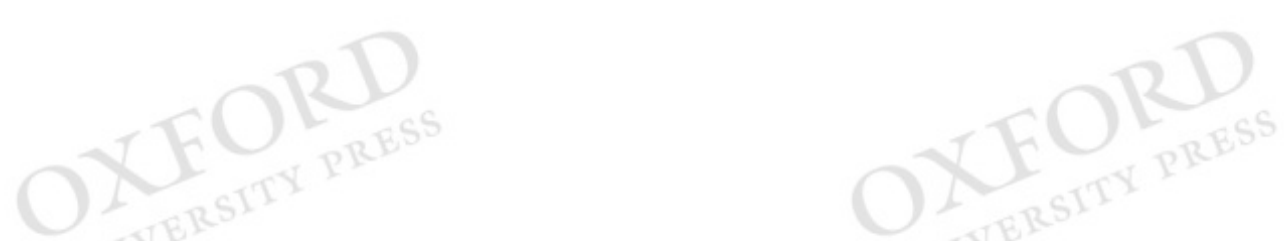